\title{
Global imbalance, rebalancing and implications for Korea
}

\author{
Jung Taik Hyun, ${ }^{*}$ Jun Yeop Lee** and Jin Young Hong ${ }^{* * *}$
}

\begin{abstract}
This paper examines global imbalance and rebalancing issues from the viewpoint of Korea. As IMF (2009) notes, the unwinding of global imbalance seems inevitable and, in fact, it is in progress. We illustrate that Korea, with a flexible exchange rate system and relatively balanced current accounts, has little direct linkage to global imbalance. However, we also find that Korea is not immune to the costly adjustment process of imbalance due to the triangular trade between Korea, China and the U.S. The fact that Korea is 'indirectly' linked to global imbalance limits Korea's ability to cope with the situation. Boosting domestic demand, often mentioned recommendation for East Asia, is not an appropriate solution for Korea with low personal savings rate. A lot depends on China's policy. If China reduces its dependence on U.S. market and increases domestic consumption despite unemployment risk in export manufacturing sector, it will provide Korea with an opportunity for more stable growth based on China's final demand. Korea can also make efforts to increase economic integration and expand monetary cooperation in Asia that would help to increase consumption demands and final goods trade in the region.
\end{abstract}

Keywords: global imbalance, rebalancing, savings rate, tri-angular trade between Korea, China, and U.S., economic integration in East Asia.

Submission Date: 11/16/2009

Revision Date: 12/11/2009

Acceptance Date: 12/11/2009

* Corresponding Author, Professor, College of Economics and International Trade, Inha University. 253 Yonghyun-Dong, Nam-Gu, Incheon, Korea. Tel: +82 32860 7802. E-mail: jthyun@inha.ac.kr,

** Professor, College of Economics and International Trade, Inha University. 253 Yonghyun-Dong, Nam-Gu, Incheon, Korea. Tel: +82 32860 7804. E-mail: jylee@inha.ac.kr

*** Ph.D. Candidate, College of Economics and International Trade, Inha University. 253 Yonghyun-Dong, Nam-Gu, Incheon, Korea. E-mail: whoktop@gmail.com 


\section{Introduction}

What would be the consequences of an adjustment of the global imbalance for Korea's economy? Global imbalance, characterized by a huge U.S. current account deficit and offsetting surplus of Asian countries among others, was pointed out as the underlying cause of the economic crisis. While there are different opinions on the cause and remedy for global imbalance, rebalancing seems inevitable considering U.S. consumer's behavior change after the burst of the financial bubble. As the IMF (2009) has already assessed, the financial crisis has been accelerating the adjustment of global imbalance and the U.S. current account deficit is, in fact, being reduced. In this context, Asian countries can not be free from the effects of global rebalancing processes. So, this can be a challenge to trade surplus Asian countries and to the Korean economy which heavily depends on trade.

In this paper, we examine the global imbalance and rebalancing issues from the perspectives of Korea. We would like to show that Korea, with a flexible exchange rate system and relatively balanced current account, has contributed little to global imbalance. Unlike China, boosting domestic demand at the expense of exports would not be an appropriate policy option. This does not mean that Korea will not be affected from the rebalancing process of Asia. China is the No. 1 trading partner of Korea. Currently, a large portion of Korea's trade with China and other Asian countries involves intermediate goods for final destination to the U.S. Will this pattern continue? The answer depends on the evolution of global production schemes and, in particular, the policy choices of China. If China reduces its dependence on its export manufacturing sector and increases domestic consumption, it will provide Korea with an opportunity for more stable growth based on China's final demands. Although signals are mixed, China seems to have taken steps in this direction. Korea, for its own part, can help to increase its market expansion in Asia by promoting regional trade and monetary cooperation.

In Section 2, we describe the pattern of global imbalance in the world and how it has evolved over time. The unwinding process after the global economic crisis is also explained. In Section 3, we examine the trends of Korea's current account and analyze how much Korea has contributed to the global imbalance. From the national income account, Korea's savings rate and investment rate are compared. We find that Korea is not an ever accumulating surplus or producing savings glut country. In Section 4, we examine the indirect linkage of Korea to the global imbalance. We describe that a large portion of Korea's exports to China are in the form of raw materials and intermediate goods that will be finally exported to the U.S. and other advanced countries. Since, China as well as the U.S. are at the core of the global imbalance problem, the tri-angler trade pattern between Korea, China and the U.S. implies that Korea is not immune to the adverse effects of unwinding global imbalance. In section 5, we draw policy implications for Korea and other countries. In the final section, we summarize the results of our study. 


\section{Evolution of global imbalance and adjustment after the Global Economic Crisis}

Global imbalance refers to the phenomenon of continuing and expanding current account deficits of countries being matched with accumulating surpluses in other countries of the world. As is well known, on the deficit side, the U.S. is named as the core of the global imbalance situation. But also, many EU members including the U.K., Italy, Spain and eastern European countries have accumulated current account deficits. On the surplus side, Japan has been a typical surplus country. However, the phrase "global imbalance" is more associated with China with its current account surplus of 10\% of GDP and a foreign currency reserve of about 2 trillion U.S. dollars. Other surplus countries include oil exporters and Asian nations including Singapore, Hong Kong, Taiwan, Malaysia and the Philippines.

Since the late 1990s, 'global imbalance' accumulated gradual attention from academia and policy makers. Figure 1 shows the magnitude of global imbalance measured in absolute sum of current account balances in percent of the world GDP. In 1991, the sum was about 2 percent of the world GDP and stayed at the similar level during the early 1990s. In the late 1990s, it began to increase and by 1999, it reached the 3 percent level. The global imbalance was accelerated during the 2004-2006 period and the absolute sum of the current account balance amounted to almost 6 percent of the world's GDP. Beginning in 2007, global imbalance seemed to be at a standstill and actually reduced a bit in that year and further in 2008 due to the recent economic recession.

Global imbalance evolved with the U.S. current account deficit and related savings and consumption pattern of U.S. households. In the 1990s, the amount the U.S. borrowed from the rest of the world was relatively small because U.S. households saved enough to finance most of their investment needs. With continuous monetary easing and asset prices rising, savings rates declined and consumption increased over time. The result was the expansion of the current account deficit and corresponding borrowing from foreign countries. As a result, the U.S. deficit increased to more than 6\% of the GDP in 2006 (Figure 2). ${ }^{1}$

\footnotetext{
1 The figure also shows that U.S. deficit reduced in 2007 and further in 2008 reflecting the unwinding
} process of global imbalance as explained later. 


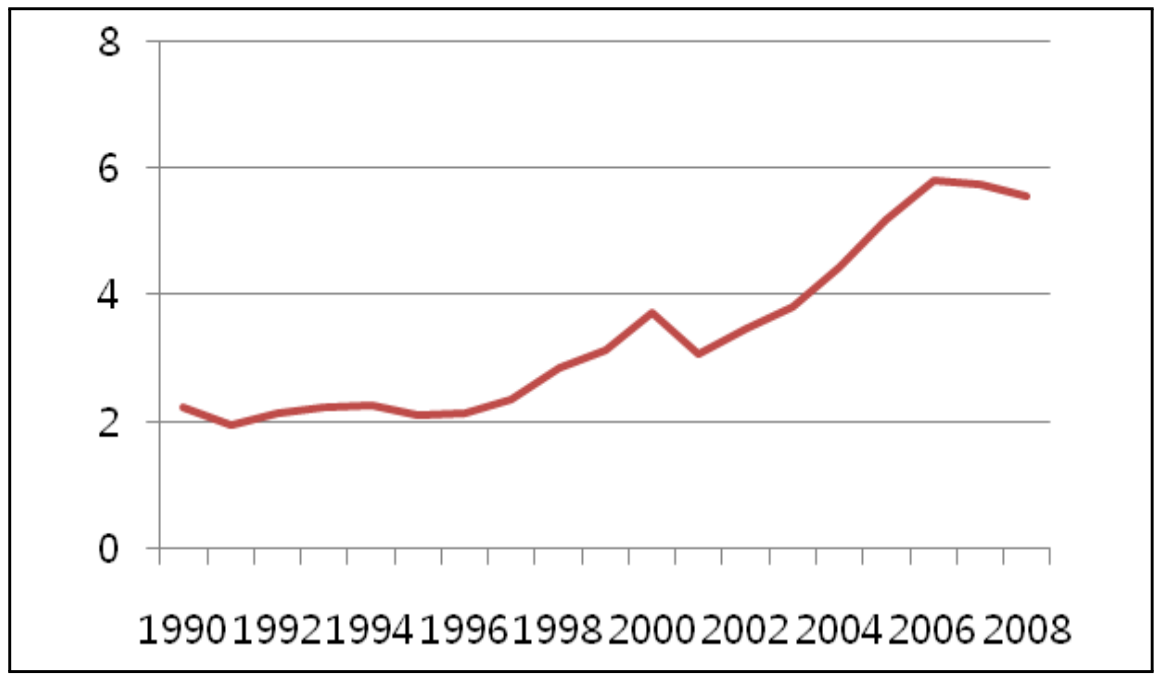

*Absolute sum of current account balances in percent of world GDP Source : IMF, World Economic Outlook 2009.

Figure 1. Global Imbalance*

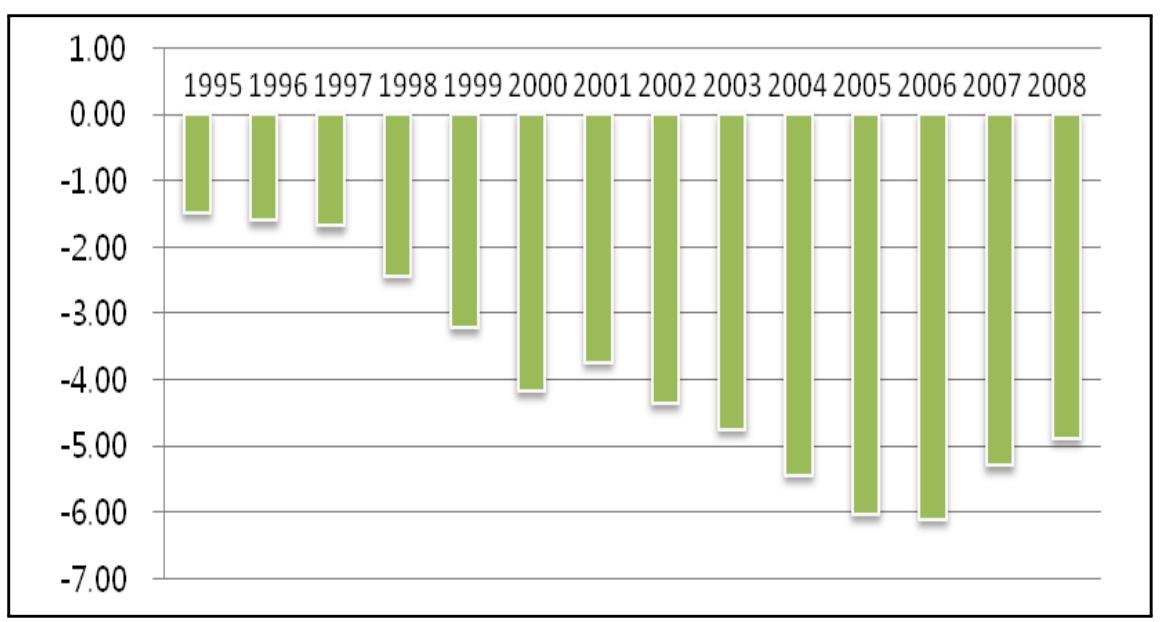

Source : KOSIS (Korean Statistical Information Service, www.kosis.kr)

Figure 2. U.S. Current Account Deficit as percent of GDP 
As for the surplus side of imbalance, China's current account surplus expanded at a faster pace than U.S. deficit expansion. China's current account surplus was $\$ 17.4$ billion or 1.3\% of GDP in 2001 (Figure 3). It increased to $\$ 68.6$ billion (3.6\%) in 2004 and reached $\$ 344.6$ billion (10.2\%) in 2007. China’s large current account surplus, to some extent, reflects the competitiveness of Chinese industry. However, the extra-ordinary pace of its evolution certainly deserves attention. In less than a decade the current account surplus expanded about 20 times in absolute amount and even as a share of the GDP, it increased by more than 5 times.

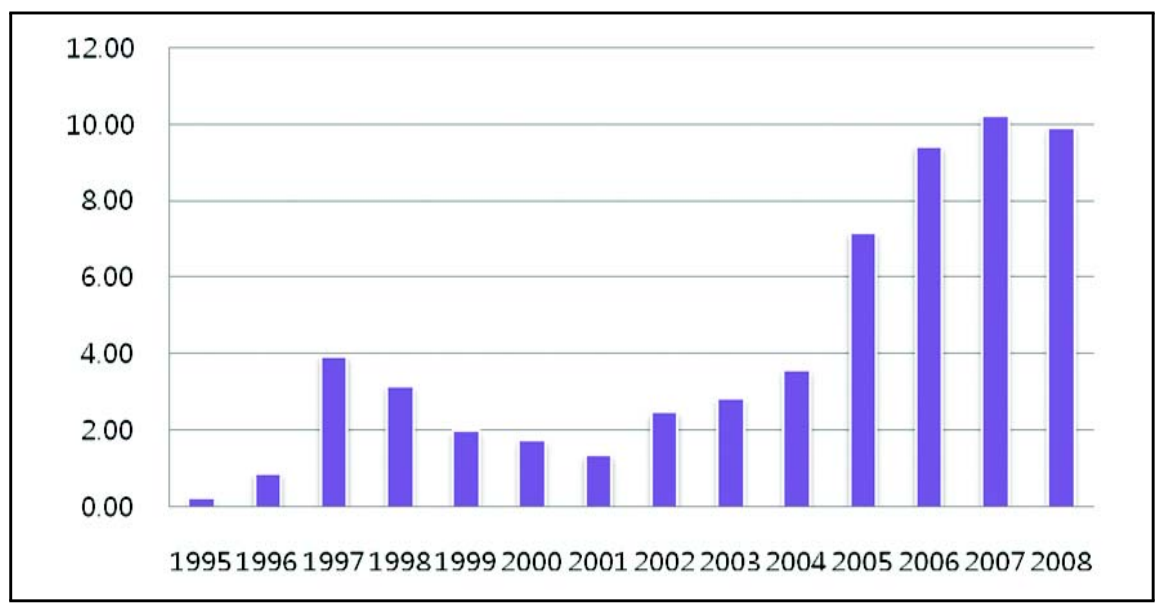

Source : KOSIS

Figure 3. China's Current Account Surplus as percent of GDP

The composition of global imbalance is shown in Table 1 in terms of stock of net foreign assets in percent of world GDP. As of 2008, the U.S. had net foreign assets of $-7.3 \%$ and the EU had $-3.7 \%$. These two are the major deficits and hence debtor regions in the world. On the surplus or credit side, Japan had net foreign assets of $4.0 \%$, emerging Asia $3.6 \%$ and oil exporters $4.2 \%$. While debt was concentrated in the U.S., credit was somewhat evenly distributed among the three major groups. We need to note, however, that stock figures reflect the accumulation of the past and that the recent dominating surplus region is emerging Asia, notably China. 
Table 1.

Net Foreign Asset in percent of World GDP

\begin{tabular}{c|c|c|c|c|c}
\hline & United States & Euro Area & Japan & Emerging Asia & Oil exporters \\
\hline \hline 1997 & -2.83 & & 3.17 & 0.29 & 0.77 \\
\hline 1998 & -3.09 & -1.99 & 3.85 & 0.65 & 0.64 \\
\hline 1999 & -2.57 & -1.72 & 2.66 & 0.41 & 0.80 \\
\hline 2000 & -4.39 & -1.83 & 3.61 & 1.09 & 1.22 \\
\hline 2001 & -6.12 & -1.45 & 4.27 & 1.21 & 1.28 \\
\hline 2002 & -6.45 & -2.69 & 4.41 & 1.76 & 1.44 \\
\hline 2003 & -5.92 & -3.12 & 4.32 & 2.03 & 1.52 \\
\hline 2004 & -5.65 & -3.29 & 4.26 & 2.36 & 1.78 \\
\hline 2005 & -4.57 & -2.60 & 3.38 & 2.37 & 2.31 \\
\hline 2006 & -4.90 & -3.27 & 3.68 & 2.59 & 3.03 \\
\hline 2007 & -4.47 & -3.97 & 3.98 & 2.80 & 3.44 \\
\hline 2008 & -7.33 & -3.74 & 4.04 & 3.64 & 4.21 \\
\hline
\end{tabular}

Source : IMF, World Economic Outlook 2009.

There are conflicting views regarding the cause and consequence of global imbalance. The optimistic view is that the global imbalance reflects decisions made by firms and households based on the market situation. For example, Cooper (2005) and Dooley, Forkerts-Landau and Garber (2004) point out that foreigners are willing to accumulate U.S. financial assets due to their perceived high liquidity and sophisticated protection. From this perspective, the situation is not very alarming because market forces will eventually resolve the imbalances over time. The pessimistic view is that global imbalance is the result of structural problems or policy failures. Bernanke (2005) sees that 'savings glut' after the Asian foreign exchange crisis in 1997 was a major cause of the global imbalance. Eichengreen (2006) points out that the imbalance is the result of the deficiency in the current international monetary arrangement and reserve system. The pessimistic view, in general, emphasizes the need for 'major' adjustment of global imbalance. Roubini and Sester (2004) warn that in the absence of a major adjustment of global imbalance, a hard landing of the U.S. and global economy is inevitable. 
Testing the validity of these different views regarding global imbalance is beyond the scope of this paper. Our focus is on the adjustment of the imbalance after the global economic crisis. Although the direction of causality is unclear, global imbalance has a strong relationship with the financial bubble that led to the current economic crisis. Asset prices rise, financial derivative and expansion of leverage helped U.S. consumers to expand their consumption. Excessive consumption was reflected in current account as deficit. While the wealth effect of housing and financial asset continued, consumption increased and hence the U.S.'s current account deficit also accumulated. After the outbreak of the economic crisis, however, people awoke from financial illusion and were compelled to make adjustments in their consumption and savings patterns. As a result, rewinding of global imbalance took place. There were already signs of adjustment of global imbalance even before the Lehman Brothers bankruptcy. The U.S.'s current account deficit was narrowed from $\$ 811$ billion (6.1\% of GDP) in 2006 to $\$ 739$ billion (5.3\% of GDP) in 2007, and further decreased to $\$ 706$ billion (4.9\%) in 2008.

The IMF (2009) assesses, "In any event, the financial crisis accelerated the adjustment of global current account imbalance."2 The IMF predicts that the U.S.'s current account deficit will narrow from a peak of 6 percent in 2006 to about 3.25\% of its GDP in 2009. The modulating of global imbalance involves quite a substantial change in U.S. business and consumer behavior. Considering the size of the U.S. economy, the impact of the unwinding process to trading partners of the U.S. will also be significant. Change equivalent to about $3 \%$ of U.S. GDP - the size of the IMF prediction of U.S. deficit reduction - is about $\$ 400$ billion. This amount is larger than the total current account surplus of $\$ 344$ billion of China, the biggest surplus country, in 2007. Current account deficits are also contracting sharply in the U.K. and other European countries as credit booms are reversed. It implies that the adjustment process on the surplus side of the global imbalance will also be broad.

Although the unwinding process started as a result of the global economic crisis, it is highly unlikely that global imbalance will resume after we overcome this crisis. The adjustment of imbalance is not a cyclical or temporary movement but more of a reflection of behavior change after the recognition of deficiency in the current system. In this regard, we need to be very careful in interpreting and forecasting the world trade flow. After the financial turmoil in the fall of 2008, world trade contracted very rapidly. Before the Lehman Brothers bankruptcy, many East Asian countries experienced 10-30\% export growth. After the outbreak of the financial turmoil, East Asian countries exhibited 20-30\% reductions in trade in the last months of 2008 and this trend continued in the first half of 2009. The World Bank and IMF forecast that the total world trade would be reduced by more than $10 \%$ in 2009. If the world economy recovers from the current crisis, trade will also be resumed. However, the world and East Asian countries cannot return to the past expeditious trade growth or patterns of trade either due to the adjustment of global imbalance.

\footnotetext{
2 The IMF, World Economic Outlook 2009, p 36.
} 


\section{Global imbalance and Korea - direct linkage}

The previous section illustrates that emerging Asia is a major surplus group in the world and thus a global imbalance contributor. Thus, countries in Asia are called upon to make the necessary adjustment to reduce global imbalance. Although, the differences of countries in Asia is mentioned in the literature, Asia as a whole is suggested to reduce its excessive current account surplus and take measures to increase domestic consumption and to adopt flexible exchange rates. ${ }^{3}$

In this section, we examine the direct link of Korea to global imbalance. Figure 4 illustrates Korea's current account balance in percent of GDP from 1995 to 2008. From 1995 to 1997, Korea experienced current account deficit that became one of the factors that caused the foreign exchange crisis in 1997. Korea experienced large current account surplus in 1998 and 1999 but that was the result from a policy reaction recommended by the IMF as conditions for remedy loans. After the crisis recovery, Korea's current account surplus was reduced to less than $1 \%$ in 2002. During the period of 2003 - 2004, Korea's current account surplus increased to $4 \%$ reflecting somewhat undervalued Korea's currency at that time. From 2005, the current account surplus was reduced substantially to 0.6\% in 2006 and 2007. In 2008, Korea exhibited deficit, which even caused concerns for the possibility of another foreign exchange crisis. Korea's evolution of balance of payment exhibits sharp contrast to that of China shown in Figure 3. While China increased current account surplus tremendously in recent years (from 3.6\% in 2004 to 9.9\% in 2008), Korea's current account surplus has been reduced to balanced or negative positions during the same period. This also reflects that Korea has adopted a relatively flexible exchange rate system.

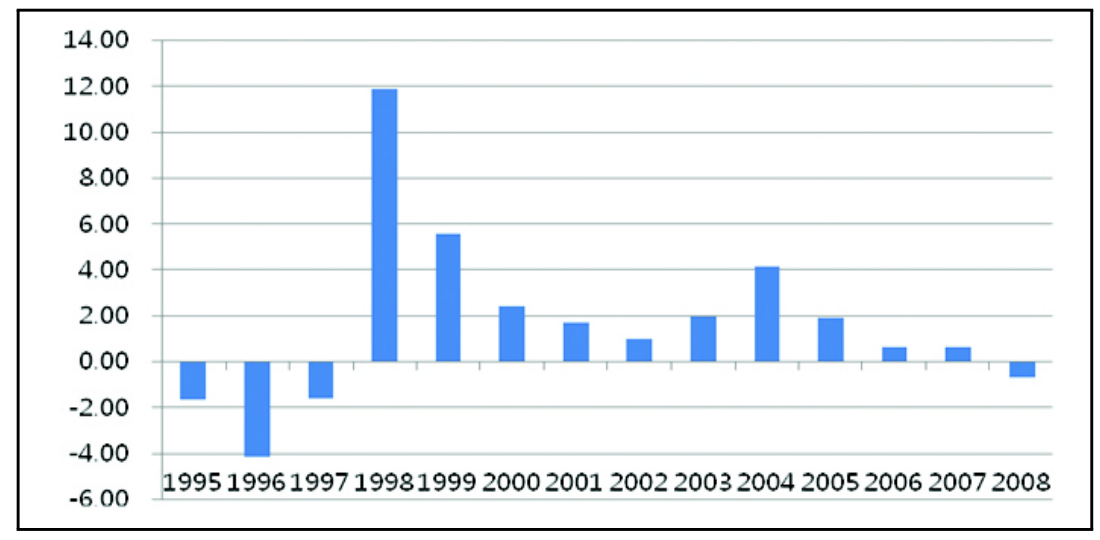

Source : KOSIS

Figure 4. Korea’s Current Account Balance as percent of GDP

\footnotetext{
3 See Adams and Park (2009) for example.
} 
In Figure 5, we compare Korea's current account position with two NIES (Singapore and Taiwan) and two ASEAN countries (Malaysia and the Philippines). Singapore exhibited huge current account surplus throughout the time and it increased to over 20\% of GDP in 2003-2006. Taiwan's surplus, 8.2\% in 2007, is smaller than that of Singapore, but much higher than that of Korea and also increased in recent years. Hong Kong is not shown in the graph, but the current account surplus is over 10\%. Among ASEAN countries, Malaysia had a big current account surplus of $16.8 \%$ of GDP, and the Philippines also accumulated a surplus from 2004, albeit modest in size (3.7\% in 2007). Some members of ASEAN experienced deficit (notably Vietnam) rather than surplus, but as a group, the ASEAN region accumulated current account surplus and thus contributed to global imbalance. So, we find that while all the other members of NIE (newly industrialized economies) and some surplus countries of ASEAN actually exhibited an acceleration of imbalance, Korea moved in the direction of balancing the surplus.

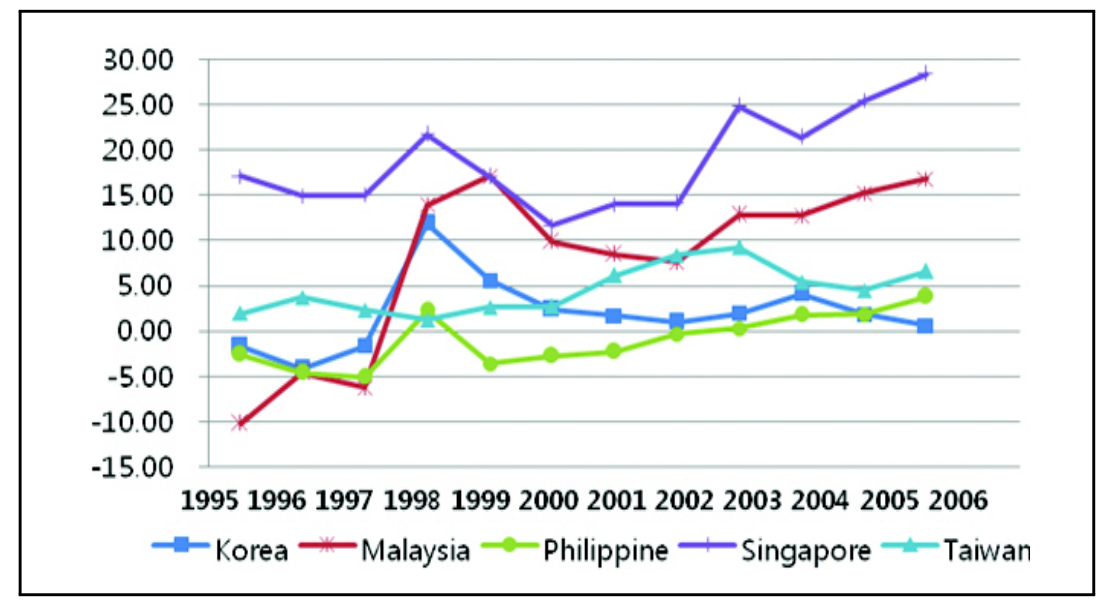

Source : KOSIS

Figure 5. Comparison of Current Account Position of Korea and Selected Countries in Asia (in percent of GDP of the country)

To understand better the picture of imbalance, we need to look into the macroeconomic framework of a country. Many people see the current account strictly through the lens of cross border flows: a deficit country imports more than it exports. But this means, in effect, that the country uses more than it produces. In other words, the country is not saving enough to meet its investment needs. The surplus country consumes less and saves more from its national income. ${ }^{4}$ In this context, Asia's 'savings glut' is often mentioned as an underlying

\footnotetext{
${ }^{4}$ From the national income identity equation, $\mathrm{Y} \equiv \mathrm{C}+\mathrm{I}+\mathrm{X}-\mathrm{M}$, we can derive the relationship, $\mathrm{S}-\mathrm{I} \equiv$
} 
cause of global imbalance. If we look at China's record, such expression may not be so inappropriate (Figure 6). China's savings rate was 37.6\% in 1991, but it increased to over $40 \%$ in 1993, to $45 \%$ in 2004 and finally to over 50\% in 2006. In other words, Chinese save more than half or consume less than half of their income. Considering about one third of consumption is performed by the Chinese government, Chinese people only consume about $35 \%$ of national income. In Figure 6, we can see that China's investment rate has also remained at a higher level and shows increasing trend. The investment rate was $34.8 \%$ in 1991 and it increased to $42.3 \%$ in 2007. While both savings rates and investment rates rose, savings rates increased much faster. Therefore the savings - investment gap expanded from 2.8\% in 1991 to $8.9 \%$ in 2007. Thus China clearly illustrates a case of excessive savings over investments being matched with a huge current account surplus.

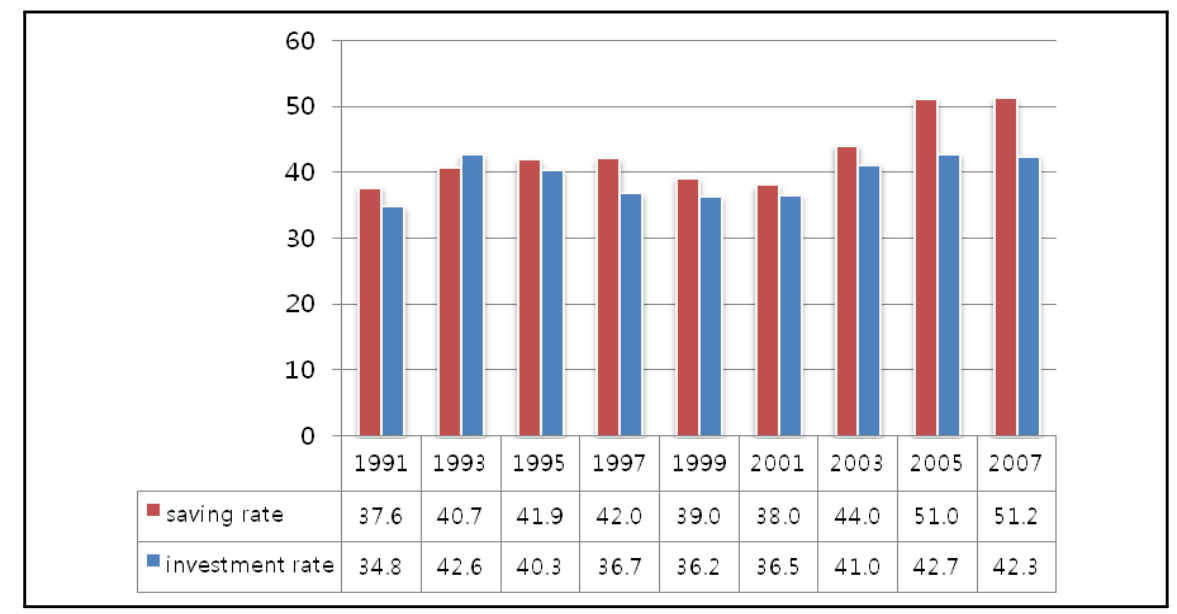

Source : China Bureau of Statistics, National Statistical Yearbook of China, 2008

Figure 6. China's Savings and Investment Rates

Korea's savings and investment rates are shown in Figure 7. Unlike China's increasing trend, Korea's savings rate decreased over time. Koreans saved 36.2\% in 1995, 33.6\% in 2000 and $30.7 \%$ in 2008. Investment rates also exhibited a decreasing trend: from $39.7 \%$ in 1995 to 33.8\% in 2000 and 31.2\% in 2008. Except in 1998 and 2004, when both savings and investment rates increased from previous years, Koreans reduced savings as well as investment over time. Importantly, Korea’s savings-investment gap was very small and very

$\mathrm{X}$-M. Therefore, the current account surplus (deficit) is equivalent to savings in excess (short) of investment.

Or it can be said that surplus (deficit) country consumes and invests less (more) than it produces. 
stable throughout most of the period. The result confirms the previous analysis of Korea's current account balance.

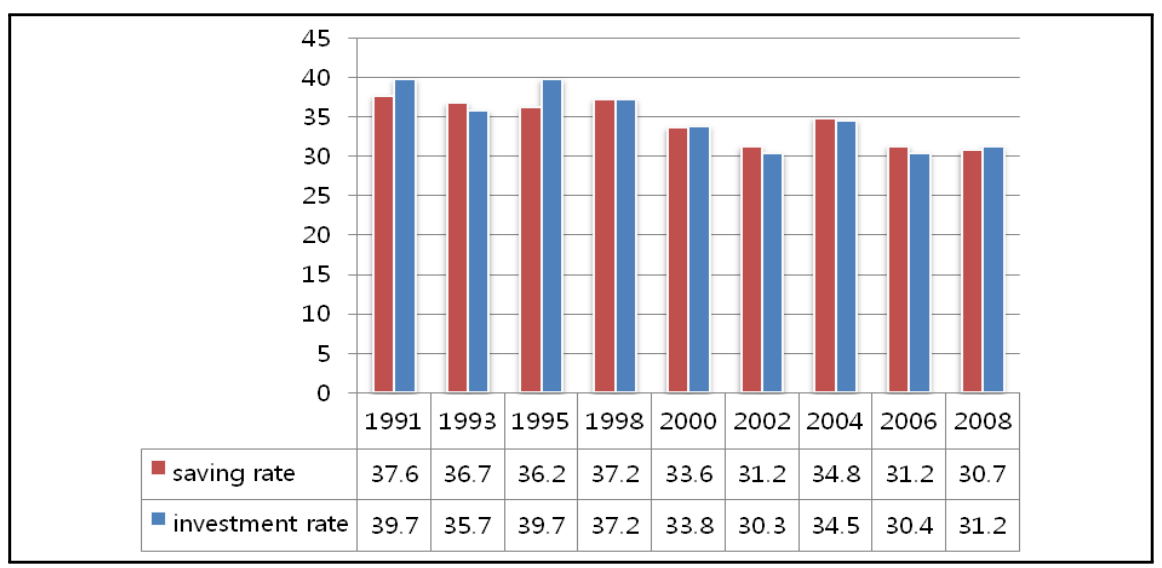

Source : KOSIS

Figure 7. Korea’s Savings and Investment Rates

We compare Korea's savings and investment rates with other surplus countries in Asia (Hong Kong, Taiwan, Malaysia and the Philippines) in Table 2. The upper part of the table shows the savings rates. We find that all five countries have had high savings rate: over $30 \%$ or a little less (Taiwan). Korea's savings rates did not exhibit much difference from other surplus countries. However, we cannot conclude that Korea's savings are excessive from the $30 \%$ savings rate. ${ }^{5}$ At the lower part of the table, investment rates of the five countries are shown. Here we find substantial differences between Korea and other countries. While Korea's investment rate, about $30 \%$, is similar to that of its savings, the other countries' investment rates are about 20\% (Hong Kong 21.3\%, Taiwan 21.1\%, Malaysia 21.9\%) or 15\% (Philippine) in 2007. Thus while other countries exhibited savings in excess of investment, Korea did not have such a gap.

\footnotetext{
5 In fact, there is concern for 'low' personal savings as well as low investment in Korea.
} 
Table 2.

Savings and Investment Rates of Selected Countries in Asia

\begin{tabular}{c|c|c|c|c|c|c|c|c}
\hline & & $\mathbf{1 9 9 5}$ & $\mathbf{1 9 9 7}$ & $\mathbf{1 9 9 9}$ & $\mathbf{2 0 0 1}$ & $\mathbf{2 0 0 3}$ & $\mathbf{2 0 0 5}$ & $\mathbf{2 0 0 7}$ \\
\hline \hline \multirow{4}{*}{ saving rate } & Korea & 37 & 35 & 35 & 32 & 33 & 33 & 31 \\
\cline { 2 - 10 } & Hong Kong & 32 & 31 & 31 & 31 & 32 & 32 & - \\
\cline { 2 - 10 } & Taipei & 27 & 26 & 26 & 25 & 28 & 27 & - \\
\cline { 2 - 10 } & Malaysia & 34 & 37 & 35 & 32 & 34 & 30 & - \\
\cline { 2 - 10 } & Philippines & 19 & 20 & 32 & 32 & 29 & 30 & - \\
\hline \multirow{4}{*}{\begin{tabular}{c} 
investment \\
\cline { 2 - 10 }
\end{tabular}} & Korea & 36 & 35 & 35 & 31 & 32 & 32 & 30 \\
\cline { 2 - 10 } & Hong Kong & 34 & 34 & 25 & 25 & 22 & 21 & 21 \\
\cline { 2 - 10 } & Taipei & 25 & 24 & 24 & 18 & 18 & 21 & 21 \\
\cline { 2 - 9 } & Malaysia & 44 & 43 & 22 & 24 & 23 & 20 & 22 \\
\cline { 2 - 9 } & Philippines & 23 & 25 & 19 & 19 & 17 & 15 & 15 \\
\hline
\end{tabular}

Source : KOSIS

Although Korea is noted for its trade dependency and for its success story based on the so-called East Asian model, from Korea's current account balance and the savings investment gap of the national income account, we find that tremendous difference exists in the balance of payment position and consumption (and savings) behavior between Korea and other countries in Asia (China, Singapore, Hong Kong, Taiwan, Malaysia and the Philippines). Korea is not an ever accumulating surplus or producing savings glut country.

\section{Global imbalance and Korea - Indirect linkage}

In order to assess the overall impact of global imbalance on the Korean economy, we need to examine indirect linkage through the triangular trade pattern. In 2008, Korea's exports to China were $22.4 \%$ of its total exports, its exports to ASEAN were $12.2 \%$ and its total exports to developing countries shared more than 60\%. Exports to the U.S. were $11.6 \%$, EU $14.6 \%$ and Japan $7 \%$, so these three groups of advanced countries, where the global crisis hit hard and consumption decreased, absorbed only about one third of Korea's exports. However, if we take into account intermediate goods exports that went first to China and were finally exported to the U.S. and other advanced countries, the picture looks quite different. Zhang (2008) assessed that US consumers still account for more exports from Korea than Chinese consumers if indirect exposure of trade is accounted. 
Gaulier, Lemoine and Unal-Kesenci (2005) explain this triangular trade pattern emerged between China, more industrialized Asia (e.g. Korea, Taiwan and Hong Kong) and western markets (the U.S. and EU). In many sectors, China is used as an export base by firms from Korea. Intermediate goods are exported to China and after processing, they are re-exported to the U.S. and EU as finished products. Therefore, decrease in China's exports to the U.S. and EU will result in decrease in Korea's exports to China in the form of processed materials and intermediate goods. ${ }^{6}$ Recent data confirms this (Table 3 and Table 4). China's exports increased $27.2 \%$ in 2006, 25.2\% in 2007 and for the three quarters before the outbreak of financial turmoil it increased at more than 20\% (Table 3). China's imports, of which a large portion is to supply the parts and materials for processing export products, also increased: $20.0 \%$ in 2006, 20.8\% in 2007 and more than $25 \%$ during the first three quarters of 2008. After the global financial shock, China's exports began to decrease and it recorded $-19.7 \%$ in the first quarter and further $-22.6 \%$ in April in 2009. Imports of China reduced at a faster pace than exports: -30.8\% in the first quarter and -23.0\% in April in 2009.

Since China is the No.1 trading partner of Korea and due to the nature of Korea-China trade, Korea's export performance has also deteriorated (Table 4). Korea's total exports increased by $14.1 \%$ in 2007, 23.1\% in the second quarter, and $27.0 \%$ in the third quarter of 2008. Of them, exports to China increased by $18.0 \%$ in $2007,33.7 \%$ in the second quarter and $21.4 \%$ in the third quarter of 2008. After the global shock, Korea's total exports recorded $-9.9 \%$ in the last quarter of $2008,-25.0 \%$ in first and $-20.0 \%$ in the second quarter of 2009. Among them, exports to China recorded $-23.9 \%$ in the last quarter of $2008,-25.1 \%$ in first and $-20.7 \%$ in the second quarter in 2009 . We can see that, in general, the change in Korea's exports to China exceeds that of total exports and thus Korea-China trade was an important factor in overall export performance of Korea.

\section{Table 3.}

China's Trade before and after the Financial Shock

(\% growth over the same period of previous year)

\begin{tabular}{c|c|c|c|c|c|c|c|c|c|c|c}
\hline & \multirow{2}{*}{$\mathbf{2 0 0 5}$} & $\mathbf{2 0 0 6}$ & $\mathbf{2 0 0 7}$ & \multicolumn{6}{|c|}{$\mathbf{2 0 0 8}$} & \multicolumn{3}{c}{2009} \\
\cline { 5 - 11 } & & Year & $\mathbf{1 Q}$ & $\mathbf{2 Q}$ & $\mathbf{3 Q}$ & $\mathbf{4 Q}$ & $\mathbf{1 Q}$ & $\sim$ April & April \\
\hline \hline $\begin{array}{c}\text { Export } \\
(\%)\end{array}$ & 28.4 & 27.2 & 25.7 & 17.2 & 21.4 & 22.4 & 23 & 4.3 & -19.7 & -20.5 & -22.6 \\
\hline $\begin{array}{c}\text { Import } \\
(\%)\end{array}$ & 17.6 & 20.0 & 20.8 & 18.5 & 28.6 & 32.4 & 25.7 & -8.9 & -30.8 & -28.5 & -23 \\
\hline
\end{tabular}

Source : KIEP (Korea Institute for International Economic Policy), Regional Economic Focus, Vol.3, No.21

\footnotetext{
${ }^{6}$ This triangular pattern is not exclusively found in China's trade and other countries including ASEAN also have this pattern, to some extent. However, China is typical in the sense that its processing industries play dominating role in trade.
} 
Table 4.

Korea's Trade before and after the Financial Shock

(\% growth over the same period of previous year)

\begin{tabular}{c|c|c|c|c|c|c|c|c}
\hline & \multirow{2}{*}{$\mathbf{2 0 0 6}$} & \multirow{2}{*}{$\mathbf{2 0 0 7}$} & \multirow{2}{*}{$\mathbf{2 0 0 8}$} & \multicolumn{3}{|c|}{$\mathbf{2 0 0 8}$} & \multicolumn{2}{|c}{$\mathbf{2 0 0 9}$} \\
\cline { 5 - 9 } & & & & $\mathbf{2 Q}$ & $\mathbf{3 Q}$ & $\mathbf{4 Q}$ & $\mathbf{1 Q}$ & $\mathbf{2 Q}$ \\
\hline \hline Export to World (\%) & 14.4 & 14.1 & 13.6 & 23.1 & 27.0 & -9.9 & -25.0 & -20.0 \\
\hline Import from World (\%) & 18.4 & 15.3 & 22.0 & 30.5 & 42.8 & -9.0 & -32.9 & -36.1 \\
\hline Export to China (\%) & 12.2 & 18.0 & 11.5 & 33.7 & 21.4 & -23.9 & -25.1 & -20.7 \\
\hline Import from China (\%) & 18.4 & 15.3 & 22.0 & 30.5 & 42.8 & -9.0 & -32.9 & -36.1 \\
\hline
\end{tabular}

Source : KDI (Korea Development Institute), Monthly Economic Trends, various issues

China's role increased due to the rapid growth in international vertical specialization, a process by which firms separate the stages of production across countries according to comparative advantage. The critical factor is the role of China as an assembly center of the world in the vertical production integration. Despite the fact that intra-regional trade and financial linkages have, in general, risen more rapidly than inter-regional ones, Asia as a whole still depends considerably on demand from the U.S. and Europe. The central role of China has had the dual effect of deepening economic interdependence between China and Korea (and other Asian countries) as well as between China and advanced countries like the U.S. and Europe. Since the latter relationship is subject to the global imbalance adjustment, the former one (China - Korea) is also affected.

We examine the relation of U.S.-China trade and China-Korea trade by classification of goods. Based on its degree of processing, all traded goods are classified into three broad groups: primary goods, intermediary goods (including half-finished goods, parts and accessories), and goods for final demand (including final capital goods and final consumption goods). ${ }^{7}$ Table 5 illustrates the pattern of trade between the U.S. and China and Table 6 illustrates that of Korea and China. As expected, a large portion of U.S imports from China consisted of final consumption products with $37.4 \%$ share in 2008. This quite contrasts to China's imports from the U.S.: final consumption goods share of 6.1\%. The U.S. also imported other final goods from China: capital goods of 32.3\%. Altogether, final goods consisted of about 70\% of U.S. imports from China while more than 70\% of China's imports from the U.S. were raw materials, parts and accessories. This pattern of trade between the

\footnotetext{
7 This has been done by HS 6 digit code to be classified into Broader Economic Classification (BEC) code and the grouping of three categories is based on the research of Choi (2006).
} 
U.S. and China suggests that if U.S. consumption and final demand contracts as a consequence of adjustment of imbalance, China's exports are to be reduced substantially. 8

Korea's exports to China consisted mainly of half-finished industrial supplies (35.0\%) and parts and accessories of capital goods (34.4\%) in 2008. That is to say, about $70 \%$ of Korean exports to China were intermediary goods processed in China (and to be mostly exported to other countries as final products). So, if China's export market shrinks as a process of imbalance adjustment, Korean exports to China have to be reduced accordingly. Consumer goods only shared $2.9 \%$ of Korea's exports to China. Korea's imports from China also had a large portion of intermediate goods, but the final goods share $(12.1 \%$ share of consumption goods) was larger than that of Korea's imports from China.

\section{Table 5.}

The U.S. - China Trade Pattern: Trade Proportions based on BEC Code (\%)

\begin{tabular}{|c|c|c|c|c|c|c|}
\hline \multicolumn{7}{|c|}{ China to U.S. Exported } \\
\hline & & 1990 & 1995 & 2000 & 2004 & 2008 \\
\hline \multicolumn{2}{|c|}{ Primary Goods } & 5.72 & 1.46 & 1.11 & 0.53 & 0.56 \\
\hline \multirow{2}{*}{$\begin{array}{l}\text { Intermediary } \\
\text { Goods }\end{array}$} & Half-finished goods & 12.05 & 11.86 & 12.49 & 12.13 & 17.95 \\
\hline & Parts \& Accessories & 2.11 & 6.38 & 9.85 & 11.48 & 11.68 \\
\hline \multirow{2}{*}{ Final goods } & Capital goods & 8.38 & 15.91 & 19.55 & 28.79 & 32.34 \\
\hline & Consumption goods & 71.50 & 64.35 & 57.00 & 47.03 & 37.44 \\
\hline \multicolumn{7}{|c|}{ China from U.S. Imported } \\
\hline & & 1990 & 1995 & 2000 & 2004 & 2008 \\
\hline \multicolumn{2}{|c|}{ Primary Goods } & 33.82 & 31.62 & 18.36 & 23.57 & 26.75 \\
\hline \multirow{2}{*}{$\begin{array}{l}\text { Intermediary } \\
\text { Goods }\end{array}$} & Half-finished goods & 19.36 & 19.52 & 22.24 & 23.21 & 23.6 \\
\hline & Parts \& Accessories & 16.17 & 15.45 & 22.74 & 24.06 & 22.10 \\
\hline \multirow{2}{*}{ Final goods } & Capital goods & 28.13 & 28.39 & 30.28 & 23.02 & 20.93 \\
\hline & Consumption goods & 2.48 & 4.97 & 6.33 & 5.97 & 6.11 \\
\hline
\end{tabular}

Source : KITA(Korea International Trade Association, www.kita.net)

${ }^{8}$ China's final demand does not affect U.S. export much, because U.S export consists mainly of intermediate goods. So the import reduction in China after the financial outbreak is induced reduction from the global demand rather than China's spending cut.

${ }^{9}$ For detailed information of trade goods grouping, see Appendix 1. 
Table 6.

Korea - China Trade Pattern: Trade Proportions based on BEC Code (\%)

\begin{tabular}{|c|c|c|c|c|c|c|}
\hline \multicolumn{7}{|c|}{ Korea to China Exported } \\
\hline & & 1990 & 1995 & 2000 & 2004 & 2008 \\
\hline \multicolumn{2}{|c|}{ Primary Goods } & 0.10 & 5.32 & 9.19 & 0.56 & 0.88 \\
\hline \multirow{2}{*}{$\begin{array}{l}\text { Intermediary } \\
\text { Goods }\end{array}$} & Half-finished goods & 75.93 & 67.94 & 56.36 & 36.74 & 34.96 \\
\hline & Parts \& Accessories & 16.01 & 7.53 & 19.68 & 36.73 & 34.39 \\
\hline \multirow{2}{*}{ Final goods } & Capital goods & 4.39 & 13.17 & 9.91 & 16.19 & 18.47 \\
\hline & Consumption goods & 3.56 & 5.2 & 4.84 & 3.49 & 2.86 \\
\hline \multicolumn{7}{|c|}{ Korea from China Imported } \\
\hline & & 1990 & 1995 & 2000 & 2004 & 2008 \\
\hline \multicolumn{2}{|c|}{ Primary Goods } & 31.55 & 17.73 & 18.50 & 8.9 & 5.97 \\
\hline \multirow{2}{*}{$\begin{array}{l}\text { Intermediary } \\
\text { Goods }\end{array}$} & Half-finished goods & 60.91 & 55.29 & 31.93 & 32.81 & 42.00 \\
\hline & Parts \& Accessories & 0.44 & 5.53 & 15.87 & 18.53 & 20.72 \\
\hline \multirow{2}{*}{ Final goods } & Capital goods & 1.63 & 4.42 & 13.85 & 18.29 & 18.28 \\
\hline & Consumption goods & 5.42 & 16.99 & 19.83 & 19.58 & 12.10 \\
\hline
\end{tabular}

Source : KITA

We need to examine whether there have been any changes in the trade patterns and more importantly, whether or not the patterns of China's trade have changed since the global crisis. Figure 8 and Figure 9 recapture the trade patterns highlighting the final demand of traded goods. We note that consumer goods are still the biggest portion of China's exports to the U.S. but this portion has been reduced over time. So, we can interpret that while consumption change in the U.S. as a result of unwinding imbalance matters, capital goods demand reduction reflecting business cycle also explains the export reduction of China.

Looking at Korea's export to China, we also find a change in the pattern. Processed industrial supplies (half-finished goods) used as materials for labor-intensive industries such as textiles and clothes were replaced by capital goods and parts. This reflects that China's major exportable goods have changed from simple goods to more complicated and capital intensive goods. However, the consumer goods share of Korea's exports to China which was 
quite low did not exhibit much change. While Chinese export diversification from a labor-intensive to capital-intensive industry is an improvement, the low and stable level of consumer goods import in China poses concern with respect to global imbalance. If China continues to depend on exports without expanding consumption, decrease in U.S. consumption will lead to decrease in China's exports and will inevitably reduce Korea's exports to China. 10

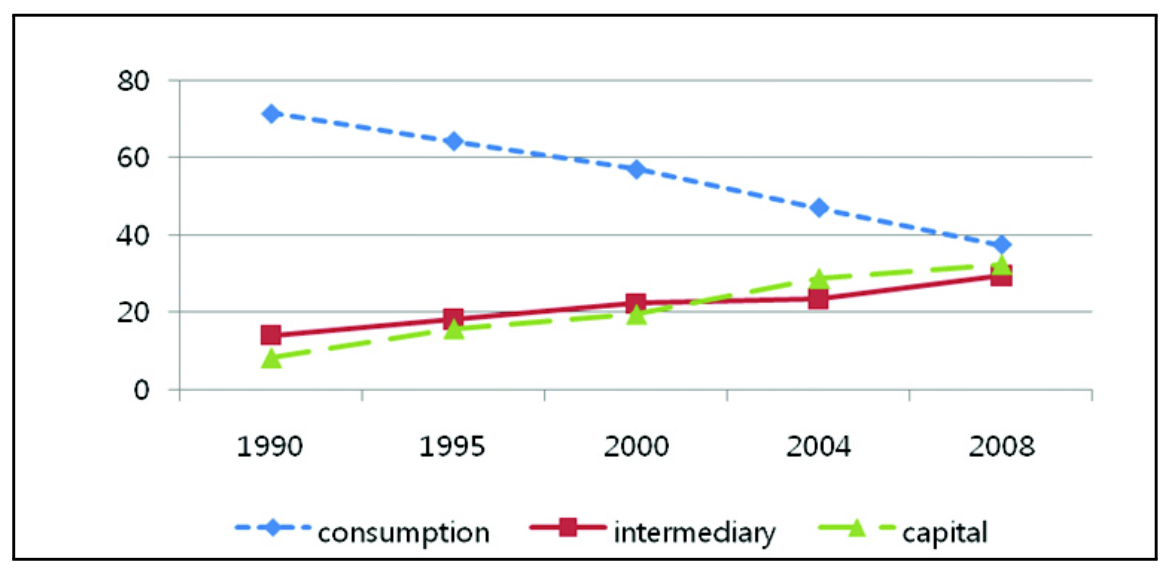

Figure 8. Pattern of the U.S. Import from China: Consumption and Capital Goods Share 1990-2008

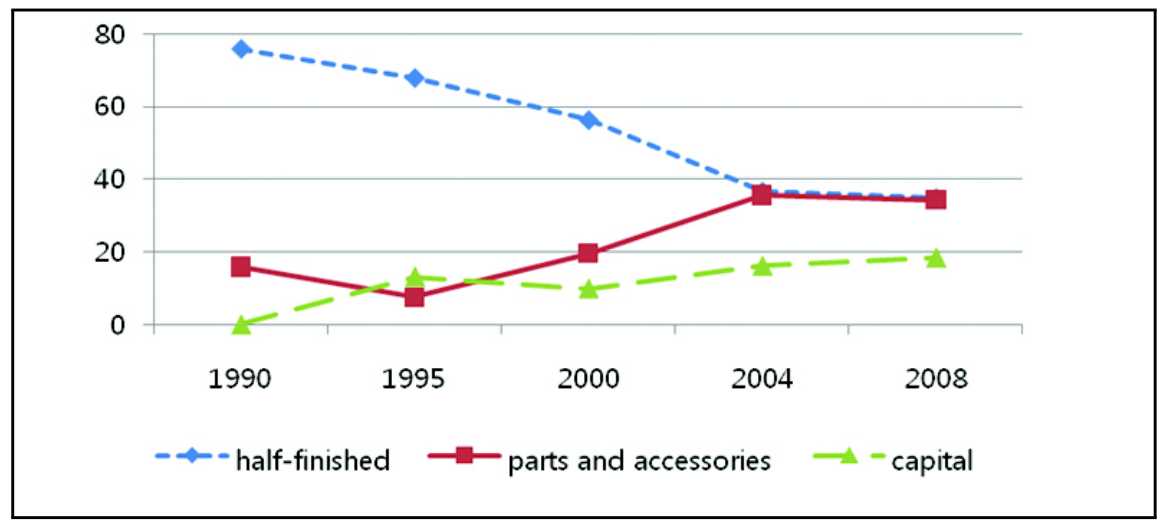

Figure 9. Pattern of Korea's Export to China: Capital Goods and Intermediary Goods including Parts and Half-finished Goods.

10 The figures described here do not fully reflect the effect of Chinese government's stimulus package of RMB 4 trillion aimed to expand domestic demand announced in late 2008. 


\section{Policy implications}

The recent financial crisis made the adjustment of global imbalance inevitable. Although Korea has little direct linkage to the global imbalance, Korea is not immune to the adverse effect of unwinding global imbalance due to indirect linkage through trade with China. Edwards (2005a, 2005b) asserts that an 'abrupt' adjustment to the order of 3 to 6 percent of U.S. GDP tends to produce negative effects on GDP growth of the U.S. and its trading partners in the world. The IMF predictions of U.S. current account reduction from 6\% in 2006 to $3.25 \%$ of GDP in 2009 would be close to qualifying as an abrupt adjustment. The current slowdown of the world economy reflects, to some extent, the adjustment cost of global imbalance.

Negative growth of the Korean economy after the financial shock also in part came from the consequence of unwinding global imbalance. Cho (2009) explains that the deterioration of the Korean economy in the fourth quarter of 2008 was caused by three factors: trade dependent structure, the collapse of the Chinese economy, and massive capital withdrawal from Korea. The first two factors are related to the indirect linkage to global imbalance examined in the previous section. To the extent that the U.S. downsizes its current account deficit over an extended period of time, we will face a more lasting negative shock to exports and growth. Viewing the current slowdown as just another downturn of another business cycle would be a serious mistake. It would be prudent for policymakers to fully recognize the medium- and long-term ramifications of the unwinding of global imbalances.

The fact that Korea is 'indirectly' linked to the costly adjustment process of global imbalance limits Korea's ability to cope with the situation. A lot depends on China's policy. If China sticks to the past policy direction of trying to expand its export market in the U.S. and to build up foreign reserves and savings, it will not work, and China and Korea (and other Asian countries) have to afford fierce competition in the shrinking markets of the U.S. and EU. If China adopts an alternative policy to boost domestic demand, in particular domestic consumption, it will improve the structure of the Chinese economy and provide Korea (and other Asian countries) with an opportunity for expanding more stable intra-regional trade based on final demand in the region. China, in fact, signaled to move in the direction of encouraging domestic expenditure. The Chinese government announced a stimulus package of RMB 4 trillion, or about $\$ 586$ billion in November 2008. This figure amounts to an extraordinary 12 percent of the nation's GDP. But due to some double counting and the fact that the stimulus measures are spread over a number of years, the IMF estimates the packages is worth about 2 percent of its GDP for 2009 and 2010.

Whether China actually shifts towards a domestic demand-oriented strategy will remain to be seen. There are some potential pitfalls and hazard ahead. One is that China's recovery relies, to an extent, on expanding exports because exports create large numbers of low-skilled jobs. As unemployment increased sharply, the specter of mass social unrest, the 
Chinese leadership’s perennial nightmare, looms larger. The other is already at a high level of domestic investment, about 40\% (Section 3). Therefore, boosting domestic demand by fiscal expenditure will increase the risk of over-investment. Positive factors for restructuring China are also found. The emergence of a large and rapidly growing urban middle class expands the consumption basis. The Chinese government also introduced measures to increase domestic consumption. As part of the stimulating policy, the Chinese government gave subsidy to inland residents to buy electrical appliances. ${ }^{11}$ Although the restructuring is bound to be a difficult, protracted, and complex structural process, China should fundamentally re-engineer its development model. That will mean relying more on consumption to power growth. In addition to the short term cyclical measure, the Chinese government should make system improvements for encouraging domestic demand. Modernizing China's backward financial system and capital markets to enable them to intermediate the country's vast savings more efficiently, loosening the grip of the state industries in the service market and investing in the education system among others are necessary steps toward this direction.

We need to be cautious not to blame trade itself for the global economic crisis. Globalization and expansion of trade is often criticized in Korea like in other countries for arousing economic problems. It must be emphasized that rebalancing does not imply turning back from the economic openness and integration into the world economy that has delivered enormous benefits for Korea and will continue to do so. Korea's export/GDP rate is 38.3\%, which is far below $212.3 \%$ of Singapore and $64.2 \%$ of Taiwan. Even compared to Germany (40.0\%), Korea's export/GDP is not much different. ${ }^{12}$ Therefore, the problem is not that Korea is excessively dependent on foreign trade. The origin of the problem is the accumulation of large surplus and deficit, and the subsequent abrupt unwinding of major trading partners of Korea. Reducing trade dependency will reduce exposure to outside and related fluctuation, but at the cost of giving up productive opportunity and efficiency improvement coming from economic openness. Having noted that trade is and will be still important for Korea, we would also like to point out the need for removing policy 'distortions' that favor the production of tradable goods over non-tradables. In particular, regulations in the service sectors of Korea hinder competition and cause inefficiency. As a result, competitiveness in the service industries fell below that of advanced economies. Service sector trade experienced a chronic deficit, which made merchandise trade surplus necessary for keeping the balance. Therefore, improving the service sector efficiency and resource allocation for non-tradable sectors including education, healthcare, environment protection and $R \& D$ is needed for future growth of Korea, and the balanced and stable growth of its trade.

\footnotetext{
11 Not only Chinese residents but also Korean companies supplying main parts of electrical appliances to China benefited from the measure.

12 The export/GDP data used here are those of 2007, except Singapore's 2006 data.
} 
Related issues of reducing export dependency and thus boosting domestic demand is savings and investment. It is often mentioned that Asia should increase its domestic demand instead of being heavily dependent on export. As we have seen in Section 3, this assertion may make sense for the countries like China that maintain a huge amount of current account surplus. However, the same argument does not seem to be warranted for Korea, in which current account fluctuates around balance. Any permanent and sizable increase in domestic demand, unless accompanied by a parallel increase in exports, must imply a current account deficit. The aggregate saving rate of Korea has been in a declining trend since the foreign exchange crisis, as bank credits became readily accessible to consumers. In particular, the net saving rate of the Korean household has declined very rapidly from around 20 percent before the crisis to around 3 percent in 2007. The OECD (2009) forecasts that Korea will record the lowest personal savings rate among OECD countries in 2010. The current saving rate of the Korean household is so low that many economists are worried about its negative implications on the financial market stability and future consumption potential.

As stated earlier, Korea has limited policy options and Korea alone cannot do much to deal with the global adjustment process. However, Korea can make efforts to increase cooperation that will contribute to an appropriate and less costly rebalancing process of global imbalance in Asia. Faced with the structural decrease in demand from the U.S., it is necessary for Asia to seek other demand sources to make up for this gap. While intra-Asian trade has superficially experienced impressive growth in recent years, much of it is trade in intermediate goods geared toward exporting final goods outside the region. More robust domestic demand for final goods within the regional countries will allow for more substantive intraregional trade along the lines of the European Union. In this regard, regional trade agreements in Asia should be revitalized. So far Asian countries have negotiated and signed multiple Free Trade Agreements (FTAs) with the countries in and outside the region. However, a comprehensive agreement (like EU) covering Asia is unlikely to be realized in the near future. Korea has tried to form an FTA with Japan, but the negotiation is at a stalemate. Korea has researched a FTA with China, but formal negotiations have not yet started. An institutional arrangement for regional integration would certainly contribute to the trade expansion within the region. In order to expand the trade for final demand goods that are crucial in rebalancing the imbalance, the coverage of FTAs in the region should be broad enough to include politically sensitive consumption items. Also, service sectors that are relatively closed in many countries in Asia should also be included to induce domestic demand-oriented growth.

Another area that needs cooperation between Asian countries is currency or monetary cooperation. As ADB (2009) notes, the Asian foreign exchange crisis in 1997 aroused the need for monetary cooperation in Asia. The Chiangmai Initiative, a mechanism to facilitate currency swap among East Asian countries was agreed. But the facility is not secure enough to guarantee safety for preventing another foreign exchange risk. Therefore, many countries 
in Asia sought to build up their own foreign exchange reserves, which became one of the reasons for global imbalance. So, if Asia can strengthen monetary and foreign exchange cooperation after this global economic crisis, the need for future build up of foreign exchange reserve and consequently the possibility of the recurrence of global imbalance will be reduced. In this regard, foreign exchange rates in Asia should be allowed to move flexibly reflecting market supply and demand. China's role again is very important here. If China tries to keep its currency undervalued to increase the sales of its exports in the global markets, this step would amount to a wrenching transition whereby China, once the engine of global growth, would be transformed into an exporter of deflation into what is already a deflationary global economy. The pressure on other Asian exporters like Korea, Taiwan, Indonesia, and Singapore would be devastating, coming on top of the problems already visited upon those economies by the collapse in global trade. If China allows its currency to appreciate, Chinese consumers would be able to purchase substantially more consumer goods while simultaneously helping to rebalance the Chinese economy (Thorbecke, 2009). Of course, Korea and other countries in Asia also should refrain from the temptation to increase competitiveness via exchange rates to expand markets in advanced economies.

\section{Conclusion}

We have explained the trend of global imbalance and its rewinding process. An adjustment of the global imbalance after the financial crisis seems inevitable, and the process is not just a short term phenomenon, but has medium to long term implications. Korea is not a direct contributor to the global imbalance: Korea's current account has been balanced overtime and its savings rate has declined suggesting that it is not a savings glut country. Korea is not immune from the adjustment process, since a large portion of Korea's exports went to China as intermediate goods and finally shipped to the U.S. and EU. The critical factor is the role of China as an assembly center of the world in the vertical production integration.

The fact that Korea is 'indirectly' linked to the costly adjustment process of global imbalance limits Korea's ability to cope with the situation. However, a few suggestions from the study can be warranted. To the extent that the US downsizes its current account deficit over an extended period of time, we will face a more lasting negative shock to exports and growth. Hence, policy makers should not view the current slowdown as another business cycle but fully recognize the medium-and long-term ramifications of the unwinding of global imbalances.

Economic openness should not be blamed for the global economic crisis. Korea's trade dependency is not excessive. And, since Korea's savings rates are so low that boosting domestic demand at the expense of exports will cause a current account deficit (as depicted 
in the national income identity equation in Section 3). China's role is very important in the adjustment process. If China reduces dependence on the U.S. market and increases its domestic consumption, it will provide Korea with an opportunity for expanding more stable trade growth based on China's final demand. The political situation in China does not allow for this transition to domestic demand-oriented growth easily. However, some positive signs, including subsidy provision for consumption goods, are found.

Korea can make efforts to increase cooperation in Asia to make the adjustment process smooth and less costly. Free Trade Agreements between Korea and China with broad coverage including the service sector would help to increase consumption demands and final goods trade between the two countries. Monetary cooperation and adoption of a more flexible exchange rate system in Asia would also help to solve the current global imbalance and reduce the future possibility of a recurring imbalance.

\section{References}

Adams, Charles and Park, Donghyun 2009. Causes and Consequences of Global Imbalances: Perspective from Developing Asia. Asian Development Review. vol. 26, no. 1.

Bernanke, Benjamin S. 2005. The Global Saving Glut and the US Current Account Deficit. Board of Governors of the Federal Reserve System, Washington, DC.

Cho, Dongchul. 2009. The Korean Economy in the Swirl of Global Crisis. Paper presented at the ADB seminar.

Choi, Eui-Hyun. 2006. Trade Pattern of China's High-Tech Products and Technology Transfer. Review of International and Area Studies. Seoul National University. vol. 15, no. 1.

Cooper, Richard N. 2005. Living with Global Imbalances: A Contrarian View. IIE Policy Brief PB05-3. Institute for International Economics, Washington, DC.

Dooley, M. P., D. Folkerts-Landau, and P. Garber. 2004. The Revived Bretton Woods System: The Effects of Periphery Intervention and Reserve Management on Interest Rates and Exchange Rates in Center Countries. NBER Working Paper No. 10332. National Bureau of Economic Research, Cambridge, MA.

Edwards, Sebastian. 2005a. Is the US Current Account Deficit Sustainable? And If Not, How Costly Is Adjustment Likely To Be?. Brookings Papers on Economic Activity. 1:211-88.

2005b. The End of Large Current Account Deficits, 1970-2002: Are There Lessons for the United States?. NBER Working Paper No. 11669. National Bureau of Economic Research, Cambridge, MA.

Eichengreen, Barry. 2006. Global Imbalances: The Blind Men and the Elephant. Issues in Economic Policy 1. The Brookings Institution, Washington, DC.

Gaulier, G., Lemoine, F. and Unal-Kesenci, D. 2005. China’s Integration in East Asia: 
Production Sharing. FDI \& High Tech Trade. CEPII working paper. No. 2005-09. Roubini, N., and Setser, B. 2004. The US as a Net Debtor: The Sustainability of the US External Imbalance. Mimeo. New York University.

The IMF. 2009. World Economic Outlook. April.

The OECD. 2009. OECD Economic Outlook No. 85. June.

Thorbecke, Willem. 2009. Can East Asia be an Engine of Growth for the World Economy?. RIETI Discussion Paper Series 09-E-006.

Zhang, Zhiwei. 2008. Can Demand from China Shield East Asian Economies from Global Slow Down?. Hong Kong Monetary Authority Working Paper 19/2008. 


\section{Appendix: Trade goods grouping based on its degree of processing}

\begin{tabular}{|c|c|c|c|}
\hline \multicolumn{2}{|c|}{ Grouping } & $\begin{array}{l}\text { BEC } \\
\text { code }\end{array}$ & Description of BEC code \\
\hline \multirow{3}{*}{\multicolumn{2}{|c|}{ Primary Goods }} & 111 & Primary food and beverage mainly for industry \\
\hline & & 21 & Primary industrial supplies not else specified \\
\hline & & 31 & Primary fuels and lubricants \\
\hline \multirow{4}{*}{$\begin{array}{l}\text { Intermediate } \\
\text { Goods }\end{array}$} & \multirow{2}{*}{$\begin{array}{l}\text { Half-finished } \\
\text { Goods }\end{array}$} & 121 & Processed food and beverage mainly for industry \\
\hline & & 22 & Processed industrial supplies not else specified \\
\hline & \multirow{2}{*}{$\begin{array}{c}\text { Parts and } \\
\text { Accessories }\end{array}$} & 42 & Parts and accessories except transport equipment \\
\hline & & 53 & Parts and accessories for transport equipment \\
\hline \multirow{4}{*}{ Final Goods } & \multirow{2}{*}{$\begin{array}{l}\text { Capital } \\
\text { Goods }\end{array}$} & 41 & Capital goods except transport equipment \\
\hline & & 521 & Industrial transport equipment \\
\hline & \multirow{2}{*}{$\begin{array}{l}\text { Consumption } \\
\text { Goods }\end{array}$} & 112 & $\begin{array}{l}\text { Primary food and beverage mainly for household } \\
\text { consumption }\end{array}$ \\
\hline & & 122 & $\begin{array}{l}\text { Processed food and beverage mainly for household } \\
\text { consumption }\end{array}$ \\
\hline
\end{tabular}

Note : This grouping is based on the research by Choi (2006). 